\title{
Field control of Meloidogyne incognita and root rot disease infecting eggplant using nematicide, fertilizers, and microbial agents \\ (1) CrossMark
}

\author{
Hamida Ahmed Osman ${ }^{*}$, Hoda Hussein Ameen, Moawad Mohamed, Riad El-Mohamedy and Usama Samy Elkelany
}

\begin{abstract}
Integrated regimens were conducted at Kafre- Hakim village to evaluate the efficacy of different agents in controlling root-knot nematode Meloidogyne incognita and root rot disease infecting eggplant cv. Baladi and their effects on yield production. The treatments used were either single or combined treatments of (1) fungal filtrate of Trichoderma harzianum; (2) Bacillus thuringiensis; (3) NPK, inorganic fertilizer; (4) Oxamyl, a chemical nematicide; and (5) chicken manure. The present study emphasized that all treatments exhibited variable potential activities against the rootknot nematode and root rot disease incidence and improved eggplant production. The most nematode and root rot bio suppressive agent was chicken manure single treatment. Although NPK alone showed remarkable increase in eggplant yield, the data generally showed that other combined treatments gave better results in improving yield production than single treatments. Integration of chicken manure with NPK, T. harzianum or B. thuringiensis to improve the disease-control efficacy and crop yield was more economically as well as environmentally acceptable.
\end{abstract}

Keywords: Root-knot nematode, Root rot disease, Eggplant, Bacillus thuringiensis, Trichoderma harzianum

\section{Background}

In Egypt, eggplant (Solanum melongena L.), an important solanaceous vegetable crop, is known to be extremely susceptible to root-knot nematode infection (Abd-El gawad 2014). This can make the crop more susceptible to other wilt diseases such as bacterial wilt and fusarium wilt (Tharshani and Sivapalan 2009). Eggplant is affected by several diseases, which do not let the plants grow and yield to a best of genetic potential. Among various pathogens, fungi constitute an important group as they inflict damage to crop plant caused by Phytophthora spp., Macrophomina phaseolina, Fusarium spp., Pythium spp., Rhizoctonia spp., and Sclerotium rolfsii. Symptoms were dark greenish, water-soaked spots which often girdle the stem, causing plants to wilt and die. Foliage leaf spots are often water-soaked and irregularly shaped, later becoming light brown. Fruits show similar spots; often, they enlarge to cover the entire fruit, which later dries and become mummified (Agrios 2000).

The use of chemical nematicides and/ or fungicides is one of the primary means of plant protection. However,

\footnotetext{
*Correspondence: hsawaf40@yahoo.com

Plant pathology Department, National Research Center, Giza, Egypt
}

their negative effects on environment and human health led to restricted use of most of them. Therefore, environment-friendly management tactics have been developed for controlling plant parasitic nematodes and soilborne diseases (Noling and Becker 1994 and Oka 2010). Biological seed-coating and bio-priming seed treatments are gaining importance in the management of many plant pathogens as another alternative to chemical fungicides (Conway et al. 2001). Coating seeds of many crops with bio control agents such as Trichoderma spp., Bacillus subtilis, and Psedomonas fluorescens was the most effective treatments for controlling seed and root rot pathogens (El-Mohamedy and El-Baky 2008).

The use of organic soil amendment is a traditional cultural practice to improve soil fertility and structure. Many research articles has really confirmed the efficacy of organic manure in the management of soil pathogens including root-knot nematode associated with improvement of plant growth and crop yield(El-Sherief et al. 2010, Abolusoro et al. 2012).

Another alternative tactic to chemical nematicides is the use of micro-organisms and their metabolites. Trichoderma is a genus of fast growing fungi widely distributed in soil. 
Trichoderma harzianum have been described as a promising biocontrol agent against Meloidogyne spp. (Selim et al. 2014) and reducing both fusarium wilt and nematode infection (Haggag and Amin 2001).

Moreover, numerous Bacillus species and strains especially Bacillus subtilus and Bacillus thuringiensis (Bt) have shown to suppress root-knot nematode and enhance plant growth. The later $(\mathrm{Bt})$ is a beneficial bacterium which produce large crystal proteins which are toxic to nematodes (Wei et al. 2003). Many studies confirmed the toxicity of Bt against plant pathogenic nematodes and significant increase in yield production (Ravari and Moghaddam 2015 and Elkelany 2016).

The research approach of using inorganic fertilizer NPK (containing nitrogen, phosphorus, and potassium) to control phytonematodes and maximize the crop yield has been reported by many authors (e.g. Abolusoro et al. 2012 Osman et al. 2015).

The objectives of the present work are to evaluate the integrated management of $M$. incognita and root rot disease infecting eggplant by application of single or combined preparations of $T$. harzianum, Bt, NPK, chicken manure and oxamyl, a standard chemical nematicide, in addition to studying their effects on the growth and yield of eggplant under field conditions.

\section{Materials and methods}

This field experiment was conducted during October 2015-January 2016 at kafre - Hakim village Giza Governorate Egypt. The experiment area was divided into plots each containing rows of $6 \mathrm{~m}$ long and $50 \mathrm{~cm}$ apart, and the distance between each plant was $50 \mathrm{~cm}$. The experiment was set up in completely randomized block design with ten treatments and 60 replicates (plants) for each treatment. Concentration, method and time of application are shown in Table 1.

Initial population densities of $M$. incognita were determined prior to planting time from $250 \mathrm{~g}$ subsamples of well-mixed soil from each row according to Barker (1985). After 4 months, at harvest time, eggplants were harvested for yield estimation. Final nematode soil populations were extracted (Barker 1985). The final nematode population densities of $M$. incognita juveniles in soil were determined and expressed as number/250-g soil. Data were subjected to analyses of variance, and means were compared according to Duncan (1951). Percentage nematode reduction in soil was determined according to Henderson and Tilton formula (Puntener 1981) as follows:

Nematode reduction $(\%)=\{1-(\mathrm{PTA} / \mathrm{PTB} \times \mathrm{PCB} / \mathrm{PCA})\} \times 100$

where PTA = population in the treated plot after application, $\mathrm{PTB}=$ population in the treated plot before application, $\mathrm{PCB}=$ population in the check plot before application and $\mathrm{PCA}=$ population in the check plot after application.

Bacillus thuringiensis Bt. (strain code K.) used in this study was obtained from Microbial Genetics Department, National Research Center, Giza, Egypt. Lauria Bartani (L B) medium (Davis et al. 1980) was used for bacterial culture.

Cultures of $T$. harzianum on liquid media, potato dextrose Broth (PDA), were brought by the authors from the Laboratory of Plant Pathology Department, National Research Center, Giza, Egypt.

Chicken manure was subjected to chemical analysis (Table 4) in the Department of Soil Sciences, NRC, Giza, Egypt, according to Chapman and Pratt (1961) and Jackson (1973).

Table 1 Treatments for controlling root-knot nematode, Meloidogyne incognita, infecting eggplants cv. Baladi, and root rot disease under field conditions

\begin{tabular}{|c|c|c|}
\hline Treatments & Concentrations & Methods and time of applications \\
\hline \multicolumn{3}{|l|}{ A: Single treatments } \\
\hline \multicolumn{3}{|l|}{ 1. Untreated control } \\
\hline 2. Bacillus thuringiensis Bt & $2 \times 10^{6} \mathrm{CFU} / \mathrm{ml}$ & $20 \mathrm{ml} / \mathrm{of}$ the suspension/hill at planting \\
\hline 3. NPK & $150 \mathrm{~N}$ unit/Feddan & Soil treatment at planting \\
\hline 4. Trichoderma harzianum & $10^{4} \mathrm{CFU} / \mathrm{ml}$ & $10 \mathrm{ml}$ of the filtrate/hill, at planting \\
\hline 5. Oxamyl* & $6 \mathrm{ml} / \mathrm{L} .24 \%$ liquid & $\begin{array}{l}\text { Foliar spraying, two times. The first } 1 \text { week after plants emerged and the second } 15 \text { days } \\
\text { from the first spraying }\end{array}$ \\
\hline 6. Chicken manure & 10 Tons/feddan $\left(2.5 \mathrm{~kg} / \mathrm{m}^{2}\right)$ & Thoroughly mixed with the soil before seeds were sown \\
\hline \multicolumn{3}{|c|}{ B: Combined treatments: methods + time of applications as individual treatments } \\
\hline \multicolumn{3}{|l|}{ 7. Chicken manure $+\mathrm{Bt}$} \\
\hline \multicolumn{3}{|l|}{ 8. Chicken manure + NPK } \\
\hline \multicolumn{3}{|c|}{ 9. Chicken manure $+T$. harzianum } \\
\hline \multicolumn{3}{|c|}{ 10. Chicken manure + oxamyl } \\
\hline
\end{tabular}

*Oxamyl is a systemic nematicide: Methyle- $\mathrm{N}-\mathrm{N}$-dimethyl-(N-(methyl)carbomycocyl-1-Thioxamidate 
The $\mathrm{pH}$ value of the examined soil using a glass electrode pH-meter (Jackson 1973) averaged 7.4.

\section{Results and discussion}

Effect of the different treatments on nematode population

Data presented in Table 2 revealed that all treatments resulted in variable significant decreases in M. incognita population in soil, root galls and egg masses compared to the untreated control. Moreover, the yield of the crop was improved in all treatments. The percentage reduction in $M$. incognita, second stage juveniles $\left(\mathrm{J}^{2}\right)$, in the soil was decreased by $81.2,76.5,70.1,64.4$, and $61.6 \%$ with single treatments of chicken manure, Oxamyl, T. harzianum, NPK, and Bt respectively as compared with untreated control. Oxamyl single treatment resulted in the greatest percentage reduction 78.7 and $71.2 \%$ in $M$. incognita egg masses and root galls respectively as compared to untreated control. However, Bt single treatment exhibited the lowest percentage reduction $54.9 \%$, and $35.2 \%$ in nematode egg masses and root galls respectively as compared to untreated control.

In case of combined treatment of chicken manure + either $\mathrm{Bt}$ or $T$. harzianum, data revealed a higher decrease in root galls and egg masses than each of single treatment. Application of chicken manure $+T$. harzianum resulted in the greatest percentage reduction 68.3 and $77.2 \%$ in $M$. incognita root galls and egg masses respectively compared to $T$. harzianum single treatment.

However, the combined treatment of chicken manure + the nematicide oxamyl was less effective than oxamyl single treatment. The percentage reduction were 54.3, 60.1 , and $70.1 \%$ for nematode juveniles in the soil, root galls and egg masses respectively compared to oxamyl single treatment.

\section{Root rot incidence of eggplant in response to different soil treatments}

Recorded data in Table 3 reveals that application of either single or combined treatments with oxamyl or chicken manure resulted in 100\% reduction in root rot disease infection and severity compared to untreated control. T. harzianum single treatment suppressed root rot disease infection by $75 \%$ and disease severity by $86.7 \%$ compared to untreated control. While the combined treatment of chicken manure $+T$. harzianum resulted in reduction percentages of both disease infection and severity by $100 \%$ compared to $T$. harzianum alone. The same trend was found in the case of the combined treatment with chicken manure + NPK which increased percentage reduction by 50 and $83.2 \%$ for disease infection and severity respectively compared to NPK single treatment.

Also, data presented in Table 3 shows that the oxamyl single treatment resulted in the greatest percentage reduction $95 \%$ in total fungi counts compared with untreated control. Followed by T. harzianum alone or plus chicken manure by $92 \%$ reduction for each of them. The least percentage reduction, $43.2 \%$, in total counts was observed in Bt single treatment; however, the combined treatment with chicken manure increased the reduction to $74.2 \%$ in total counts.

\section{Effect of different treatments on eggplant production}

All treatments showed significant increases in eggplant yield compared to the control. NPK alone produced the highest eggplant yield $93.0 \%$ as compared to control,

Table 2 Effects of Bacillus thuringiensis, NPK, Trichoderma harzianum, oxamyl and chicken manure on eggplants cv. Baladi infected with the root-knot nematode, Meloidogyne incognita, under field conditions

\begin{tabular}{|c|c|c|c|c|c|c|c|c|c|}
\hline \multirow[t]{2}{*}{ Treatments } & \multicolumn{3}{|c|}{ No. of $\mathrm{J}^{2}$ in $250 \mathrm{~g}$ soil } & \multicolumn{2}{|c|}{ No. of root galls in 5 (g) roots } & \multicolumn{2}{|c|}{ No. of egg masses in $5(\mathrm{~g})$ roots } & \multicolumn{2}{|c|}{ Eggplant production } \\
\hline & Initial pop. & Final pop. & $\%$ Red. & No. & $\%$ Red. & No. & $\%$ Red. & Weight (g) & $\%$ Inc. \\
\hline Control & 270 & $986 \mathrm{a}$ & - & $191.6 \mathrm{a}$ & - & $184.4 \mathrm{a}$ & - & $2150.0 \mathrm{j}$ & - \\
\hline Bacillus thuringiensis (Bt) & 230 & $322 f$ & 61.6 & $124.0 \mathrm{~b}$ & 35.2 & $83.0 \mathrm{~b}$ & 54.9 & $2650.0 \mathrm{~h}$ & 23.0 \\
\hline NPK & 250 & $325 \mathrm{~h}$ & 64.4 & $74.0 \mathrm{~cd}$ & 61.3 & 46.2 ef & 74.9 & $4151.0 \mathrm{a}$ & 93.0 \\
\hline Trichoderma harzianum & 280 & $305 \mathrm{~g}$ & 70.1 & $75.4 \mathrm{~cd}$ & 60.6 & $62.0 \mathrm{~cd}$ & 66.3 & $2438.0 \mathrm{i}$ & 13.1 \\
\hline Oxamyl & 245 & $210 i$ & 76.5 & $55.0 \mathrm{~d}$ & 71.2 & $39.2 f$ & 78.7 & $2749.0 \mathrm{~g}$ & 27.0 \\
\hline Chicken manure & 365 & $250 \mathrm{~h}$ & 81.2 & $70.8 \mathrm{~cd}$ & 63.0 & $51.6 \mathrm{e}$ & 70.0 & $3849.6 c$ & 79.0 \\
\hline Chicken manure $+\mathrm{Bt}$ & 210 & $342 \mathrm{e}$ & 55.4 & $74.8 \mathrm{~cd}$ & 60.9 & $47.8 \mathrm{cf}$ & 74.0 & $3642.6 \mathrm{~d}$ & 69.0 \\
\hline Chicken manure + NPK & 360 & $432 c$ & 67.1 & $78.4 \mathrm{C}$ & 59.0 & $64.6 \mathrm{c}$ & 64.9 & $4107.2 \mathrm{~b}$ & 91.0 \\
\hline $\begin{array}{l}\text { Chicken manure }+T \text {. } \\
\text { harzianum }\end{array}$ & 285 & $442 b$ & 57.5 & $60.6 \mathrm{~cd}$ & 68.3 & $42.0 \mathrm{f}$ & 77.2 & $3200.0 \mathrm{f}$ & 48.8 \\
\hline Chicken manure + Oxamyl & 220 & $367 d$ & 54.3 & $76.4 \mathrm{~cd}$ & 60.1 & 55.0 de & 70.1 & $3453.4 \mathrm{e}$ & 60.6 \\
\hline
\end{tabular}

Each value represents mean of five replicates. Means followed by the same letter(s) within a column are not significantly $(P \leq 0.05)$ different according to Duncan's multiple range test

No. number, $\%$ Red. $\%$ reduction, $\%$ Inc. \% increase, Initial pop. initial population, Final pop. final population 
Table 3 Root rot incidence of eggplant in response to different soil treatments of Bacillus thuringiensis, NPK, Trichoderma harzianum, oxamyl and chicken manure under field conditions

\begin{tabular}{|c|c|c|c|c|c|c|}
\hline Treatments & Disease infection & $\%$ Red. & Disease severity & $\%$ Red. & Total fungi counts & $\%$ Red. \\
\hline Control & $20.0 \mathrm{a}$ & - & $0.6 \mathrm{a}$ & - & $12.4 \mathrm{a}$ & - \\
\hline Bacillus thuringiensis (Bt) & $10.0 \mathrm{c}$ & 50.0 & $0.3 b$ & 50.0 & $7.2 \mathrm{~b}$ & 43.2 \\
\hline NPK & $15.0 \mathrm{~b}$ & 25.0 & $0.2 \mathrm{~b}$ & 66.7 & $4.8 \mathrm{~b}$ & 61.6 \\
\hline Trichoderma harzianum & $5.0 \mathrm{~d}$ & 75.0 & $0.08 c$ & 86.7 & $0.9 \mathrm{c}$ & 92.4 \\
\hline Oxamyl & $-\mathrm{e}$ & 100.0 & $-c$ & 100.0 & $1.9 \mathrm{c}$ & 95.0 \\
\hline Chicken manure & $-e$ & 100.0 & $-c$ & 100.0 & $2.4 \mathrm{~b}$ & 80.8 \\
\hline Chicken manure $+\mathrm{Bt}$ & $5.0 \mathrm{~d}$ & 75.0 & $0.05 c$ & 91.6 & $3.2 \mathrm{~b}$ & 74.2 \\
\hline Chicken manure + NPK & $10.0 \mathrm{c}$ & 50.0 & $0.1 \mathrm{c}$ & 83.3 & $1.2 \mathrm{c}$ & 90.0 \\
\hline Chicken manure $+T$. harzianum & $-\mathrm{e}$ & 100.0 & $-\mathrm{c}$ & 100.0 & $0.7 \mathrm{c}$ & 92.0 \\
\hline Chicken manure + oxamyl & $-\mathrm{e}$ & 100.0 & $-c$ & 100.0 & $1.2 \mathrm{c}$ & 90.2 \\
\hline
\end{tabular}

Each value represents mean of five replicates. Means followed by the same letter(s) within a column is not significantly ( $P$ value 0.05$)$ different according to Duncan's multiple range test

$\%$ Red. Reduction

followed by $91.0 \%$ with chicken manure + NPK combined treatment and $79.0 \%$ with the chicken manure single treatment (Table 2). T. harzianum single treatment exhibited the lowest percentage increase of $13 \%$, while the combined treatment of chicken manure $+T$. harzianum resulted in $48.8 \%$ increase in eggplant yield. The percentage increase in eggplant production was increased by $69.1 \%$, and $60.6 \%$ by using combined treatment of chicken manure + Bt and chicken manure + oxamyl respectively as compared with untreated control (Table 2).

The present study emphasized that all treatments exhibited variable potential activities against the root-knot nematode and root rot disease incidence and improved yield production. The most nematode and root rot bio suppressive treatment was chicken manure single treatment. Moreover, data in Tables 2 and 3 clearly showed that the combined treatments gave better results in improving yield production than the single treatments.

The present results are in parallel with the findings of EL-Sherif and Ismail (2010) in their studies on the integrated management of $M$. incognita infecting sunflower using Trichoderma harzianum, Marigold powder, cow manure, and Bacillus thurigiensis singly or combined with oxamyl. They revealed that the concomitant applications obviously showed better results in nematode control than single treatments.

Organic amendments stimulate the multiplication of micro-organisms like fungi and bacteria. Some of these micro-organisms are parasites of nematodes. This will bring about biological suppression of parasitic nematodes in soil, hence promoting growth and development of the plants (Summers 2011).

The present results could be explained according to the $\mathrm{C} / \mathrm{N}$ ratios of organic manure. Nitrogenous compounds, mainly ammonia (NH3), are generated from organic materials with low $\mathrm{C} / \mathrm{N}$ ratios in the soil. The most popular and practical of these amendments is animal manure (Oka et al. 2007). Our results presented in Table 4 indicated that $\mathrm{C} / \mathrm{N}$ ratio of the chicken manure used in this study was (18.8: 1). Miller and Donahue (1990) reported that organic residues with $\mathrm{C}: \mathrm{N}$ ratio of $20: 1$ has sufficient nitrogen to supply the plant growth. These findings may explain the high nematicidal activity of chicken manure in this study. Improving of plant growth of eggplant may be attributed to nematode reduction and to improving soil nutrients (Akhtar and Mahmood 1997). Ammonia is generated from organic materials being decomposed by soil micro-organisms and is known to play an important role in the suppression of plant parasitic nematodes and fungi (Tenuta and Lazarovits 2002). The biocidal role of ammonia is not clear, but several mechanisms are thought to be involved. Among these is exhaustion of the chemical energy of cells of pathogenic organisms by removing cytosolic ammonia against a concentration gradient (Britto et al. 2001).

Application of organic amendments with low $\mathrm{C} / \mathrm{N}$ ratios is also effective in acidic soils for the control of soilborne diseases and nematodes. However, the suppressions are achieved more slowly in acidic soil than in natural to alkaline soils. The $\mathrm{pH}$ of the soil of the experimental field of this study was 7.4 (slightly alkaline). As already noted, the ammonia released from amendments is oxidized to nitrite in the first stage of nitrification. In acidic environment, the nitrification process is not as rapid as in alkaline

Table 4 Approximate percentage of organic matter, organic carbon, nitrogen, and phosphorus, potassium and carbon/nitrogen ratio of chicken manure

\begin{tabular}{lllllll}
\hline Chemical analytes & O. M \% & C \% & N \% & C: N \% & P \% & K \% \\
\hline Chicken manure & 64.2 & 37.3 & 2.0 & $18.7: 1$ & 0.5 & 0.9 \\
\hline
\end{tabular}

$O . M$ organic matter, $C$ organic carbon, $N$ nitrogen, $P$ phosphorus, $K$ potassium, $C: N$ ratio of chicken manure 
environments, and nitrite occasionally accumulates in the soil. Nitrite in the soil water phase is in equilibrium with nitrous acid $\left\{\mathrm{HNO}_{2}\right\}$, the non-ionized form of nitrite, and nitrous acid is known to be highly toxic to fungi and nematodes (Tenuta and Lazarovits 2002).

The present results indicated slight decrease in nematicidal efficiency in the combined treatment of chicken manure + oxamyl compared to oxamyl single treatment. It is well known that organic matter may absorb the toxic molecules of the nematicide during its degradation which may preclude its action against nematode (Noling 2009).

The inorganic fertilizer NPK single or combined treatments were effective in controlling $M$. incognita and improving eggplant yield. An outstanding increase in eggplant yield was obviously in NPK single and combined with chicken manure treatments. Concerning NPK single treatment, our results are in harmony with the findings of Abolusoro et al. (2012) who found significant reduction in the root-knot nematode Meloidogyne incognita infecting Ethiopian eggplant (Solanum aethiopicum) and increasing plant growth parameters by application of inorganic fertilizer NPK. Similar results were reported by Osman et al. (2015). They observed significant reduction in $M$. incognita infecting tomato plants as well as improving the crop yield by application of NPK under field conditions. The ameliorated growth criteria of treated eggplant suggested that nitrogen present in the fertilizer when absorbed by the plant were utilized in protein synthesis and seed production, while potassium is involved in many metabolic cellular functions through phosphorylation and water balance. There are many hypothetical mechanisms by which NPK affect nematode. Olwe (2012) suggests that the fertilizer (NPK) or its component(s) have stimulatory effect on the plant leading to an enhancement of growth. The dual effect of NPK in improving plant growth and suppressing nematode population is documented by Akhter and Mahmood (1996).

The present results indicated the positive effect of $T$. harzianum in controlling root-knot nematode $M$. incognita, root rot disease, and mild increase in yield production. These findings are in harmony with Haggag and Amin (2001), who tested the effects of Trichoderma harzianum on the root rot fungus Fusarium solani and root-knot nematode Meloidogyne javanica on sunflower. They reported a highly significant reduction in Fusarium wilt and nematode infection, as well as an increase in plant growth of sunflower in the Trichoderma-treated plants. They attributed their finding to the suppressive effects of cell wall-degrading enzymes produced by Trichoderma species. These enzymes cause degradation of chitin of fungal cell walls. Also, plant parasitic nematode eggs have thick chitin layer. Trichoderma groups produce nematicidal or nematostatic compounds, a situation which may illustrate the effects of $T$. harzianum filtrate in improving plant growth parameters and suppressing root-knot nematode $M$. incognita infecting eggplant. Yedida et al. (2000) reported that inoculation of cucumber roots with T. harzianum (T-203) induced an array of pathogenic related proteins, including a number of hydrolytic enzymes.

Trichoderma strains exert biocontrol against fungal pathogens by competing for nutrients and space or promoting plant growth and plant defense mechanisms and antibiosis. Prasad and Kumar (2011) reported that Trichoderma spp. produced non-volatile antifungal antibiotic. Selim et al. (2014) showed that T. harzianum isolate (T10) induced systemic resistance to tomato plants against the root-knot nematode, $M$. javanica, by increasing the accumulation of special different antagonistic compounds that affect nematode invasion.

Concerning Bt application, the present results obviously indicated its efficiency in controlling $M$. incognita infecting eggplant, root rot diseases, without adverse effects on yield production in both single and combined treatments. Others have shown that the spore/crystal proteins of Bt strains can produce a number of toxins with different structure and mode of action against Meloidogyne incognita (Mohammed et al. 2008). Moreover, a Bacillus thuringiensis Cry 14 toxin has been found to be effective against root-knot nematode $M$. javanica (Ravari and Moghaddam 2015). More supportive evidence to the nematicidal efficiency of Bt observed in the present study has been reported by Elkelany (2016) who investigated the efficacy of Bt thuringiensis cell suspension against $M$. javanica infecting eggplant under greenhouse conditions. He found significant nematicidal activity of bacterial suspension applied as soil drench together with improvement in eggplant growth parameters. The author refers to the potentiality of bacterial suspension to production of antimicrobial compounds and cuticle-degrading protease enzymes.

\section{Conclusions}

The results of the present work revealed that both the chemical nematicide and chicken manure produced significant reduction in nematode reproductive parameters as well as root rot disease. Moreover, the combined treatment of chicken manure plus the bio agent $T$. harzianum significantly decreased nematode root galls, egg masses and root rot incidence (disease infection, severity and total counts) accompanied by improvement in eggplant yield. Application of NPK showed remarkable increase in eggplant yield; however the lowest percentage increase in eggplant yield was shown in T. harzianum treatment; in addition, all the combined treatments significantly improved yield production.

The present work recommends the integration of chicken manure with NPK, Trichoderma harzianum or Bacillus thuringiensis, to improve the control efficacy and to increase the yield to more economically and environmentally acceptable level. 


\section{Acknowledgements}

This work was funded by a grant, code number 10120604 of In-House report from the National Research Center, Giza, Egypt.

\section{Authors' contributions}

$\mathrm{OH}$ suggested the point of research and designed the experimental work and wrote the manuscript. AH participated in the design and statistical analysis of the data. MM participated in the field work and nematode laboratory investigations. ER participated in microbial laboratory investigations. EU participated in field work and nematode laboratory investigations. All authors read and approved the final manuscript.

\section{Competing interests}

The authors declare that they have no competing interests.

\section{Publisher's Note}

Springer Nature remains neutral with regard to jurisdictional claims in published maps and institutional affiliations.

\section{Received: 30 May 2017 Accepted: 26 March 2018}

Published online: 19 April 2018

\section{References}

Abd-El gawad MMM (2014) Yield losses by phytonematodes: challenges and opportunities with special reference to Egypt. Egypt J Agronematol 13(1):75-94

Abolusoro SA, Abolussoro PF, Mathew FO (2012) Effects of organic and inorganic manures on the growth attributes of root-knot nematode (Meloidogyne incognita ) infected Ethopian eggplant (Solanum aethiopicum). Libyan Agric Res Center J Internat 3(5):224-228

Agrios, G. N., 2000. Significance of plant disease. Plant Pathology. Ed., Agrios, G. N. Acad. Press. London pp: 25-37

Akhtar, M. and I. Mahmood. 1997. Impact of organic and inorganic management and plant-based products in plant-parasitic and microbivorous nematode communities. Nematol.- Mediter 25(1): 21-23

Akhter M, Mahmood I (1996) Control of plant parasitic nematodes with organic and inorganic amendments in agricultural soil. Appl Soil Ecol 4(3):243-247

Barker, K. R. 1985. Nematode extraction and bioassay In: An Advanced treatise on Meloidogyne, Volume 11-Methodology (eds K. R. Barker, C. C. Carter and J. N. Sasser).PP. 19-35. North Carolina State University Graphics: Raleigh, North Carolina, USA

Britto DT, Siddiqi MY, Glass ADM, Kronzucker HJ (2001) Futile transmembrane $\mathrm{NH}_{4}$ cycling: a cellular hypothensis to explain ammonium toxicity in plants. Proc Nath Acad Sci U S A 98:4255-4258

Chapman, H.D. and R.E. Pratt. 1961. Methods of analysis for soil, plants and water USA. Dept. of Soil plant Nut. Univ. of California

Conway KE, Mereddy R, Kahan AB, Wa Y, Wa L (2001) Beneficial effects of solid matrix chem.-priming on okra. Plant Dis 85:535-537

Davis, R.W., D. Botstein and J. A. Rotho. 1980. Transfect ion of DNA. In Bacterial genetics: a manual for genetic engineering advanced bacterial genetic. Cold spring harbor laboratory cold spring harbor, New York., 67: 134-137

Duncan DB (1951). A significant test for differences between ranked treatments in analysis of variance. Verginia J Sci (2): 171-189

El- Sherif AG, Ismail AFA (2010) Integrated management of Meloidogyne incognita infecting sunflower by certain organic amendments, Bacillus thuringiensis and oxamyl with reference to NPK and total chlorophyll status. Egypt J Agronematol 9(1):40-51

Elkelany, U. S. 2016. Controlling of root-knot nematodes in eggplants using genetically improving bacteria. Ph.D.Thesis. Fac. Agric., Ain Shams Univ. 197pp

El-Mohamedy RSR, El-Baky MMHA (2008) Effect of seed treatment on control of root rot disease and improvement of growth and yield of pea plants. Mid East Russian J Plant Sci Biotechnol 2:84-90

El-Sherief AG, Refaei AR, Gad SB (2010) Effects of certain animal manures or plant products alone or integrated with oxamyl on growth of peanut plant infected with Meloidogyne javanica. Egypt. J. Agronematol. 9(1):30-39

Haggag WM, Amin AW (2001) Efficacy of Trichoderma species on control of fusarium-rot, root knot and reniform nematodes disease complex on sunflower. Pakistan J Biol Sci 4:314-318

Jackson, M. L. 1973. Soil chemical analysis. Practice., Hall India, New Delhi. pp. 144-197

Miller RW, Donahue RL (1990) Organic matter and container media soils; an introduction to soil and plant growth $6^{\text {th }}(E d)$. Prentice Hall, Inc., Englewood Cliffs, N. J. U. S. A., pp 181-225
Mohammed SH, El Saedy MA, Enan MR, Ibrahim NI, Ghareeb A, Moustafa SA (2008) Biocontrol efficiency of Bacillus thuringiensis toxins against root-knot nematode, Meloidogyne incogita. J of cell and Molec Biol 7(1):57-66

Noling, J. W. 2009. Movement and toxicity of nematicides in the plant root zone. University of florida IFAS. Extension. http.//edis. : Fas utl. Edu/ng 002

Noling JW, Becker JO (1994) The challenge of research and extension to define and implement alternatives to methyl bromide. J Nematol 26:573-586

Oka Y (2010) Mechanisms of nematode suppression by organic soil-amendments. A review. Appl Soil Ecol 44:101-115

Oka Y, Shapira N, Fine P (2007) Control of root knot nematodes in organic farming system by organic amendments and soil solarization. Crop Prot 26: $1556-1565$

Olwe TO (2012) The effect of fertilizer (NPK) on infestation of Meloidogyne incognita on cowpea, vigna unguiculata (L.). British J Sci 6:25-42

Osman HA, Ameen HH, Mohamed MMM, Alkelany US (2015) Effect of integrating fertilizer with micronema, compost or oxamyl on suppressing plant parasitic nematode Meloidogyne incognita infecting tomato plants under field conditions. Mid East J Agric 4(4):707-7011

Prasad, B. N. and M. R. Kumar. 2011. Effect of non-vollatalile compounds produced by Trichoderma spp. on growth and sclerotial viability of Rhizoctonia solani, Inc, tant of sheath bight of rice. Indian J. of Fundament. and Appl. Life Sci 1, 37-42

Puntener, W. 1981. Manual for field trials in plant protection- Basle, Switzerland: Agric. Division, Ciba Geigy Limited 205

Ravari SB, Moghaddam EM (2015) Efficacy of Bacillus thuringiensis cry 14 toxin against root-knot nematode, Meloidogyne javanica. Plant Protect Sci 15(1):46-51

Selim, M. E., M. E. Mahdy, M.E. Soryal, A. A. Dababat, and R.A. Sikora. 2014 Biological and chemical dependent systemic resistance and their significance for the control of root nematodes. Nematol. 001-11

Summers, H. 2011. Effects of organic manure on nematode control. Journal of Diseases and Pests Control in Tropics, 7(2): 190-191

Tenuta M, Lazarovits G (2002) Ammonia and nitrous acid from nitrogenous amendments kill the microsclerotia of verticillium dohliae. Phytopathology 92:255-264

Tharshani, N. and A. Sivapalan. 2009. Eco- friendly management of tomato rootknot nematode (Meloidogyne spp.) in Calci- Red Yellow Latasol: Environment Srilanka Blog". Phytopathology 91: 681-693. http://environmentlanka.Com/ blog/2009

Wei J, Hale K, Carta L, Platzer E, Wong E, Fangs S, Aroian V (2003) Bacillus thurigiensis crystal proteins that target nematode. Microbiol 100:2760-2765

Yedida L, Benhamou N, Kapulnik Y, Chet I (2000) Induction and accumulation of PR proteins activity during early stages root colonization by the mycoparasitic Trichoderma harzianum strain T- 203. Plant Physiol Biochem 38:863-873

\section{Submit your manuscript to a SpringerOpen ${ }^{\circ}$ journal and benefit from:}

- Convenient online submission

- Rigorous peer review

- Open access: articles freely available online

- High visibility within the field

Retaining the copyright to your article

Submit your next manuscript at $>$ springeropen.com 